\title{
THE WORKING CAPITAL MANAGEMENT EFFECT ON PROFITABILITY OF ENERGY COMPANIES IN TURKEY, BASED ON DIFFERENT BUSINESS CYCLES
}

\section{DOI: 10.17261/Pressacademia.2018.973}

PAP-IFC- V.8-2018(5)-p.18-23

\section{Oktay Tas $^{1}$, Cigdem Guleroglu Atac ${ }^{2}$}

${ }^{1}$ Istanbul Technical University, Department of Management, Istanbul, Turkey. tasokta@itu.edu.tr, ORCID: 0000-0002-7570-549X

2Istanbul Technical University, Management, 34469, ìstanbul, Turkey

gulerogluatac16@itu.edu.tr, ORCID:0000-0003-2367-0878

\section{To cite this document}

Tas, O., Guleroglu, A. C. (2018). The working capital management effect on profitability of energy companies in Turkey, based on different business cycles. PressAcademia Procedia (PAP), V.8, p.18-23.

Permemant link to this document: http://doi.org/10.17261/Pressacademia.2018.973

Copyright: Published by PressAcademia and limited licenced re-use rights only.

\begin{abstract}
Purpose - This study aims to investigate the effect of business cycle on the relation between working capital management and corporate performance.

Methodology - We examine the relation between working capital and profitability under economic down and upturns, on energy firms which are traded on Istanbul Stock Exchange and included in BISTELKT index. Working capital is measured by cash conversion cycle. EBIT to total assets ratio is used to represent profitability and business cycle is modeled by gross domestic products. Data is on quarterly basis from 2012 to 2018.

Findings - The analysis shows that there is a negative relation between cash conversion cycle and profitability during economic growth, while a reverse relation exists in economic recession periods.

Conclusion- The study shows that the efficient working capital management is important in terms of the firms' profitability, and must be included in financial planning especially in the times of economic upturns.
\end{abstract}

Keywords: Working capital management, cash conversion cycle, profitability, gross domestic products, Turkey energy company index. JEL Codes: G32

\section{INTRODUCTION}

Working capital management has been received a considerable interest of both academics and business experts for many years, because of the idea that it affects firms' profitability. Firms invest significant amounts in working capital in order to overcome their operating activities and to meet project requirements, thus; an efficient management of capital structure becomes a must for a relatively better business performance.

This study investigates the relation between working capital and profitability, specifically during the upturns and downturns of economic activity. By definition, working capital management refers to management of current assets and current liabilities. There exists several ways to measure working capital; we prefer to focus on cash conversion cycle (CCC) approach that represents the length of time in days that takes for a firm to covert its initial investment and raw material into cash out flows from sales of the finished goods. The longer the time lag, the larger the investment in working capital. The longer CCC may have a positive effect on profitability because of higher sales. On the other hand, high working capital require financing, which results in additional financing expenses, may cause loss of profitability (Deloof (2003)). We aim to examine this link between working capital and profitability using a sample of energy firms in Turkey, traded on Istanbul Stock Exchange and included in BIST energy index, under the consideration of economic expansion and recession periods between 2012 and 2018. We use earinging before interest and taxes (EBIT) to total assets ratio to represent profitability and Turkey's gross domestic products (GDP) data to model the business cycle.

This study is organised as follows. After the introduction in Section 1, related literature review is presented in Section 2. Data environment definition and calculation methodology of variables used in the analysis is described in section 3 . Section 4 is dedicated to regression model set up and analysis results. We conclude the study in Section 5. 


\section{LITERATURE REVIEW}

There are numerious studies in the literature that researches the working capital management by using the methodology of cash conversion cycle in order to understand the determinants of the investment on working capital, including the studies Wang (2002), Deloof (2003) and Gill et al. (2010) find a significant inverse relation between corporate profitability and cash conversion cycle as a measure of working capital. According to Deloof (2003) there is also a negative relation between account payable and profitability. This inverse relation is supported by Garcia and Solano (2007) together with the result of that the greater length of the cash conversion cycle led to a reduction in the levels of profitability for many firms. A further study adds on the previous one; Caballero, Garcia and Solano (2014), suggest that the negative nonlinear relation implies the existence of an optimal level of investment in working capital that balances costs and benefits and maximizes a firm's value. The results also says that managers should avoid negative effects on firm performance because of lost sales and lost fo discounts for early payments or additional financing expenses which they behave as the constraints of the optimization problem. The existence of an optimal level of working capital policy is shown in the study Aktas, Croci, and Petmezas (2015) and they claim that firms that converge to this optimal level by increasing or decreasing their investment in working capital improve their stock and operating performance.

Because of their impact on firm profitability, some control variables such as company size (natural logarithm of sales), current ratio and dept ratio are usually inserted into regression model in many studies. Our study adopts a similar methodology as in Deloof (2003), Lazaridis and Tryfonidis (2006) and Azadegan and Pai (2008).

To the best of our knowledge, a limited number of the academic researches insert the effect of business cycles, described as the rise and fall in production output of goods and services in an economy, on the working capital. Business cycle is generally measured by the downward and upward movements of gross domestic product (GDP). Enqvist, Graham and Nikkinen (2014) find that the impact of business cycle on the link between working capital and profitability is more pronounced during economic downturns relative to economic booms. According to study Einarsson and Marquis (2001), the degree of funding that rely on bank financing to cover the working capital requirements in the US, increases during the times of economic weakening.

The literature review for this study shows that, in the analysis of the relation between working capital and profitability, energy firms are generally excluded from the data because of their working capital structure. Since most of the energy firms prefer to hold low amount of inventory, the cash conversion cycles may be negative, but still represents a good benchmark among the similarly structured companies.

\section{DATA AND VARIABLES}

The firm level data used in this paper consists of the official balance sheet and income statement information of the selected firms on quarter basis between the years 2012 and 2018, retrieved from Reuters and Rasyonet platforms. The six energy firms are selected as, Ak Enerji, Aksa Enerji, Aksu Enerji, Ayen Enerji, Odaş Enerji and Zorlu Enerji, which are the firms traded on Istanbul Stock Exchange and included in BISTELKT index.

We measure working capital by the concept of cash conversion cycle, defined as:

$\mathrm{CCC}=$ (\# of days Accounts Receivable) + (\# of days Inventory) - (\# of days Accounts Payable)

The three components of CCC are estimated as follows:

$\#$ of days Accounts Receivable $=\frac{\text { Accounts Receivable }}{\text { Sales }} * 365$

\# of days Accounts Payable $=\frac{\text { Accounts Payable }}{\text { Cost of Goods Sold }} * 365$

$$
\# \text { of days Inventory }=\frac{\text { Inventory }}{\text { Cost of Goods Sold }} * 365
$$

CCC includes the expected life of working capital components which allows to predict future cash follows better than other static liquidity ratios (Enqvist, Graham and Nikkinen, (2014)). In order to measure firm profitability, we prefer to use earnings before interest and taxes (EBIT), calculated as revenue minus operating expenses, to total assets (TA) ratio rather than return on assets (ROA) ratio. Since, ROA employs net income to measure profitability, we find it more convenient to include interest expenses. Thus, profitability indicator (PRO) in this study is calculated from sample data as below.

$$
\text { PRO }=\frac{\text { EBIT }}{\text { TA }}
$$

Following Garcia and Solano (2007), Enqvist, Graham and Nikkinen, (2014), we include the control variables; company size and debt ratio into regression model, which are considered to affect a firm's profitability. Company size is taken as natural logarithm of sales. Different from the related literature, we use financial debt ratio (FDR) rather than debt ratio, to separate firms' net financial debt from total debt, calculated as follows. 


$$
\mathrm{FD}=\mathrm{LTD}+\mathrm{CPD}+\mathrm{DP}+\mathrm{NP}-\mathrm{CSTI}
$$

$$
\mathrm{FDR}=\frac{\mathrm{FD}}{\mathrm{TA}}
$$

where LTD is long term debt, CDP is current portion debt, DP is dividends payable, NP is notes payable, CSTI cash and short term investment. Figure 1 represents the development of weighted average of EBIT to TA (on the left vertical axis) and weighted average of FD to TA (on the right vertical axis) ratios of listed energy companies between 2012 and 2018 . Figure shows that FD ratio has been around $50 \%$ of TA, and had an increasing trend since 2012. EBIT / TA ratio is around 1,3\% if the extreme EBIT level realized at the end of 2013 is excluded.

\section{Figure 1: EBIT to total assets and FD to total assets}

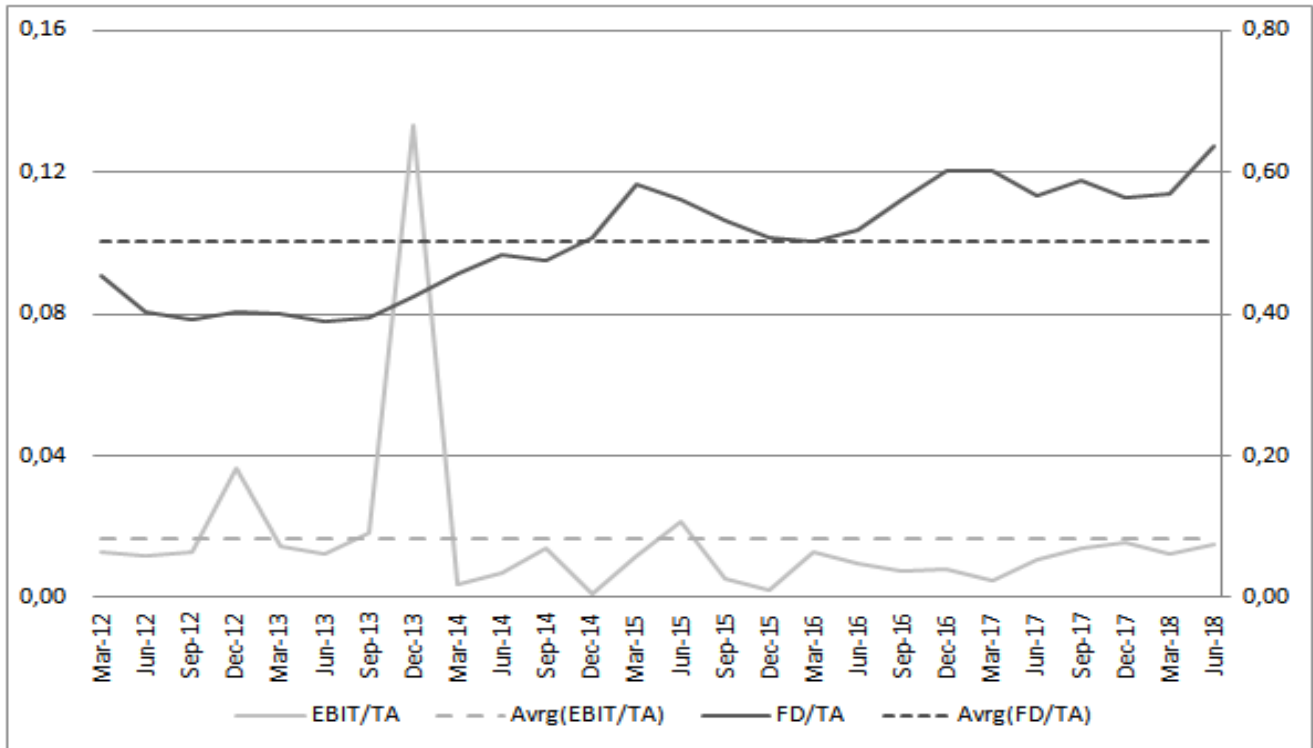

To model business cycle behaviour based on irregular fluctuations in economic activity, quarterly growth domestic products (GDP) data is used. We separate time period into two states, representing economic expansion and recession periods. We insert dummy variables into regression model, taking binary values to reflect upturns and downturns of GDP based on the previous period. These dummy variables are used to indicate the importance of working capital components in the two different states of the economy which are then compared to results from the entire study. GDP data is available at Turkish Statistical Institute website. Figure 2 demonstrates GDP trend in Turkey between 2012 and 2018

Figure 2: Turkey GDP

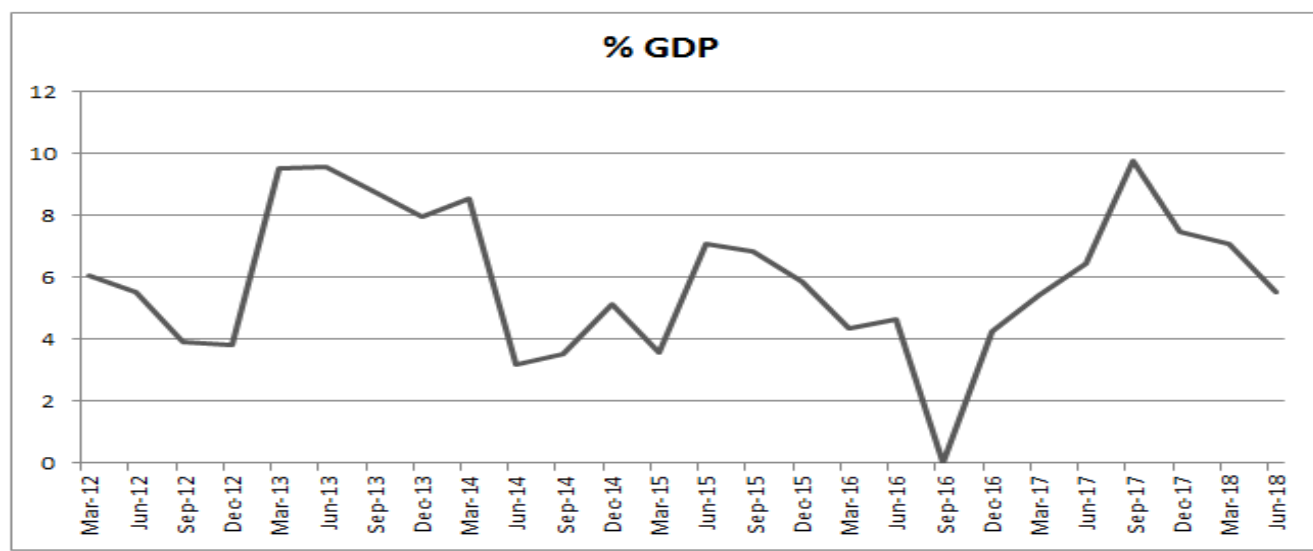

Table 1 shows the descriptive statistics for the variables used in the analysis. APDEF is account payable deferral period, ARCON and INVCON are account receivable and inventory conversion periods respectively. PRO is the profitability measure (EBIT / TA ratio), FDR is the financial 
debt ratio, and CS is the company size (natural logarithm of sales). The average CCC for the listed energy firms is negative at $-47,828$. As mentioned before, this is mainly because of low inventory levels that the enegry firms hold, results in a relatively low average INVCON at 40,986 . The average profitability is at $1,7 \%$ with $8 \%$ percent of maximum value and below $-2 \%$ of minimum value observed during the time period. Financial debt ratio is seen to be $50 \%$ at average. Company size changes between 4,605 and 7,250 with the average value of 4,452 .

Table 1: Descriptive Statistics

\begin{tabular}{|c|c|c|c|c|c|}
\hline Working Capital Management & Mean & Median & Maximum & Minimum & Std. Dev. \\
\hline $\mathrm{CCC}$ & $-47,828$ & $-35,048$ & 454,784 & $-701,821$ & 196,509 \\
\hline APDEF & 253,282 & 195,355 & 1001,143 & 0,000 & 188,370 \\
\hline ARCON & 164,467 & 150,089 & 433,724 & 0,000 & 78,450 \\
\hline INVCON & 40,986 & 1,271 & 363,510 & 0,000 & 75,030 \\
\hline Profitability & Mean & Median & Maximum & Minimum & Std. Dev. \\
\hline PRO & 0,017 & 0,010 & 0,800 & $-0,021$ & 0,066 \\
\hline \multicolumn{6}{|l|}{ Control } \\
\hline FDR & 0,503 & 0,545 & 0,919 & $-0,109$ & 0,218 \\
\hline CS & 4,452 & 5,075 & 7,250 & $-4,605$ & 2,387 \\
\hline
\end{tabular}

Table 2 demonstrates the pair wise correlations between all pairs of variables used in the analysis. We present the correlations as separated into two economic states, economic boom and recession respectively. Table shows that, as expected, there is a negative correlation between CCC and profitability, means that firms should shorten CCC to become more profitable, when the economy is in a good state. However, this relation changes direction during the economic recession period. On the other hand, firms' financial debt ratio and profitability is again have a negative relation in economic upturns, but move in the same direction when the economy is having relatively bad days. Thus, financial managers should decrease the ratio of financial debt to total assets to have more gain, during the economic growth. The company size seems to have a positive effect for both states of economy.

Table 2: Correlations

\begin{tabular}{|c|c|c|c|c|c|c|c|}
\hline Economic Upturn & PRO & $\mathrm{CCC}$ & APDEF & ARCON & INVCON & FDR & $\mathrm{CS}$ \\
\hline PRO & 1,0000 & & & & & & \\
\hline $\mathrm{CCC}$ & $-0,0430$ & 1,0000 & & & & & \\
\hline APDEF & 0,0668 & $-0,8587$ & 1,0000 & & & & \\
\hline ARCON & $-0,2029$ & 0,0695 & 0,3791 & 1,0000 & & & \\
\hline INVCON & $-0,0570$ & 0,3793 & $-0,0335$ & $-0,2383$ & 1,0000 & & \\
\hline FDR & $-0,0598$ & $-0,2715$ & 0,2398 & $-0,1424$ & 0,0627 & 1,0000 & \\
\hline $\mathrm{CS}$ & 0,0730 & 0,0338 & 0,0040 & $-0,3163$ & 0,3810 & 0,7210 & 1,0000 \\
\hline Economic Downturn & PRO & $\mathrm{CCC}$ & APDEF & ARCON & INVCON & FDR & $\mathrm{CS}$ \\
\hline PRO & 1,0000 & & & & & & \\
\hline $\mathrm{CCC}$ & 0,3112 & 1,0000 & & & & & \\
\hline APDEF & $-0,1723$ & $-0,8482$ & 1,0000 & & & & \\
\hline ARCON & 0,0818 & 0,1418 & 0,2888 & 1,0000 & & & \\
\hline INVCON & 0,3425 & 0,4381 & $-0,0730$ & 0,0639 & 1,0000 & & \\
\hline FDR & 0,0019 & $-0,3404$ & 0,4351 & 0,0679 & 0,1164 & 1,0000 & \\
\hline $\mathrm{CS}$ & 0,3126 & $-0,0786$ & 0,2317 & $-0,0017$ & 0,4025 & 0,6961 & 1,0000 \\
\hline
\end{tabular}

\section{REGRESSION MODELS}

Following the structures of models previously applied in the literature Enqvist, Graham and Nikkinen (2014) Deloof (2003), Lazaridis and Tryfonidis (2006), we regenerate the following regression models to examine the relation between profitability and CCC for both economic states.

For the purpose of evaluating the regression result under two separated economic condition, we regress the equations as below, where D1 and D2 are the dummy variables stand for economic upturns and downturns, respectively.

$\mathrm{PRO}=\alpha_{0}+\alpha_{1}$ CCC D $1+\alpha_{2}$ FDR $+\alpha_{3}$ CS

$\mathrm{PRO}=\beta_{0}+\beta_{1} C C C D O+\beta_{2} \mathrm{FDR}+\beta_{3} C S$

Table 3: Regression Results 


\begin{tabular}{|c|c|c|c|c|}
\hline Variable & Coefficient & Std. Error & t-Statistic & Prob. \\
\hline $\mathrm{C}$ & 0,01936 & 0,01012 & 1,91386 & 0,05750 \\
\hline $\mathrm{CCC}^{*} \mathrm{D} 1$ & $-0,00006$ & 0,00004 & $-1,64458$ & 0,10210 \\
\hline FDR & $-0,07060$ & 0,03767 & $-1,87415$ & 0,06280 \\
\hline CS & 0,00706 & 0,00306 & 2,30274 & 0,02270 \\
\hline \multicolumn{5}{|l|}{ Economic Downturn } \\
\hline Variable & Coefficient & Std. Error & t-Statistic & Prob. \\
\hline C & 0,01733 & 0,01023 & 1,69465 & 0,09220 \\
\hline $\mathrm{CCC}^{*} \mathrm{DO}$ & 0,00002 & 0,00001 & 1,89010 & 0,06060 \\
\hline FDR & $-0,05325$ & 0,03780 & $-1,40857$ & 0,16100 \\
\hline CS & 0,00592 & 0,00300 & 1,97566 & 0,05000 \\
\hline
\end{tabular}

Table 3 shows the regression results. We estimate the regression equation by using panel least squares method. The White cross section coefficient covariance method is employed. Coefficients are found significant at $10 \%$ significance level, except for the coefficient of FDR in economic downturn scenario. According to the results shown in Table 3, there exists a negative linear relationship between profitability and CCC when GDP growth is positive. Therefore, it is shown that CCC has a positive but almost zero impact on profitability during the negative economic growth periods. This means, financial managers should pay more attention to decrease CCC to support firm's profitability in terms of earnings, when GDP is expected to increase in the next quarter of the year. Moreover, company size, which is taken as natural logarithm of sales, always has a positive impact on profitability for our data sample. Finally, it is convenient to say that the increasing degree of financial dept to total asset ratio has a negative effect for both business cycle condition, if a more restricted significance level is considered for the second case.

\section{CONCLUSION}

This study examines the effect of the business cycle on the relation between the working capital management and corporate performance based on its profitability. Our sample data includes the energy firms are selected as the firms which are traded on Istanbul Stock Exchange and included in BISTELKT index, based on quarters between 2012 and 2018. To measure working capital management, we utilize CCC approach that includes the life of working capital components; account payable deferral period, account receivable and inventory conversion periods. To model profitability of firm, we employ EBIT/TA ratio. Business cycle condition is represented by Turkey GDP growth based on previous quarter between 2012 and 2018. The period separated into two states, one stands for the economic expansion when the GDP growth is positive, the other is economic recession with the condition of negative GDP growth. We insert two control variables into model; financial debt ratio and company size, considered to have an impact on firms' profitability.

The correlation analysis results indicate that is a negative correlation between CCC and profitability, means that firms should shorten CCC to become more profitable, when the economy is in a good state. However, this relation changes direction during the economic recession period. On the other hand, firms' financial debt ratio and profitability is again have a negative relation in economic upturns, but move in the same direction when the economy is having relatively bad days. The company size seems to have a positive effect for both states of economy.

The regression analysis results show that there exists a negative linear relationship between profitability and CCC when GDP growth is positive. This negative relation is supported by Wang (2002), Deloof (2003), Gill et al. (2010) and Enqvist, Graham and Nikkinen (2014). However, Wang (2002), Deloof (2003), and Gill et al. (2010) does not differentiate the economic condition, while Enqvist, Graham and Nikkinen (2014) finds the relation more pronounced during economic downturns relative to economic booms. Therefore, in this study, it is shown that CCC has a positive but almost zero impact on profitability during the negative economic growth periods. This means, financial managers should pay more attention to decrease CCC to support firm's profitability in terms of earnings, when GDP is expected to increase in the next quarter of the year. Moreover, company size, as natural logarithm of sales, always has a positive impact on profitability for our data sample. Finally, it is convenient to say that the increasing degree of financial dept to total asset ratio has a negative effect for both business cycle condition, if a more restricted significance level is considered for the second case. Thus, regression results are compatible with the results of correlation analysis.

\section{REFERENCES}

Wang, Y.J., (2002). Liquidity management, operating performance and corporate value: evidence from Japan and Taiwan. J.Multinational Financial Manage. 12 (2), 159-169.

Deloof, M., (2003). Does working capital management affect profitability of Belgian firms? J. Business Finance Acc. 30 (4), $573-587$.

Garcia-Teruel, P.J., Martinez-Solano, P., (2007). Effects of working capital management on SME profitability. Int. J. ManagerialFinance 3 (2), 164-177.

Gill, A., Biger, N., Mathur, N., (2010). The relationship between working capital management and profitability: evidence from theUnited States. Business Economics J. 10, 1-9. 
Enqvist, J., Graham, M., Nikkinen, J.. (2014). The impact of working capital management on firm profitability in different business cycles: Evidence from Finland. Research in International Business and Finance 32(2014) 36-49.

Baños-Caballero,S., García-Teruel, P..J, Martínez-Solano, P., (2014). Working capital management, corporate performance, and financial constraints. Journal of Business Research 67 (2014) 332-33.

Aktas, N., Croci, E., Petmezas D., (2015). Is working capital management value-enhancing? Evidence from firm performance and investments. Journal of Corporate Finance 30 (2015) 98-113.

Einarsson, T., Marquis, M.H., 2001. Bank intermediation over the business cycle. J. Money Credit Banking 33 (4), $876-899$.

Lazaridis, I., Tryfonidis, D., 2006. Relationship between working capital management and profitability of listed companies onthe Athens Stock Exchange. J. Financial Management Anal. 19 (1), 26-35.Azadegan and Pai (2008)

L-Shubiri, F. N. (2015). The Impact of Economic and Financial Variables on Cash Conversion Cycle of Energy, Oil and Gas Sectors Listed in Muscat Security Market. International Journal of Energy Economics and Policy Vol. 5, No. 1, 2015, pp.174-181, ISSN: 2146-4553.

Dritsaki, C., Dritsaki, M. (2014), Causal relationship between energy consumption, economic growth and CO2 emissions: A dynamic panel data approach. International Journal of Energy Economics and Policy, 4(2), 125-136. 